\title{
Cinematic Technique in Maurice Gee's Hostel Girl
}

\author{
Vivien van Rij
}

\section{Introduction}

Award winning writer of novels for children and adults, Maurice Gee has had a long association with the filmic worlds of cinema and television. Visually evocative, many of Gee's novels have been made into good films. In My Father's Den (based on Gee's novel of the same name), and Fracture (based on Gee's Crime Story) were released within months of each other in 2004, and were both highly acclaimed. Similarly, The Champion (Gee's second realistic children's novel) was quickly made into a successful television movie, whilst Under the Mountain (Gee's first fantasy novel for children), was made into a television series in 1981, and then a movie in 2009. Gee has also been involved in script writing for television drama, which perhaps accounts for the strong handling of dialogue in his novels. Indeed, The Fire-Raiser (Gee's first realistic children's novel) was originally written as a television script at the request of film-maker Ginette McDonald, and only after that re-worked as a novel.

Gee's novels are not only visually evocative in a way that allows them to be effectively transposed into film, but they also allude to well-known movies and show them to influence characters' actions and thoughts. As Bill Manhire has commented: "Films in fact are influential in the environment of Gee's [ . . . ] fiction. They supply stylized models of 'real life' which provincial and adolescent New Zealand might aspire to, they make a difference to behaviour". Manhire suggests that the "tough-guy eloquence" in the mannered tone of Gee's novel, The Big Season, is picked up partly from Hollywood movies. Interestingly, noting in the same novel Rob's and Carol's attendance at The House of Wax (a horror film), Manhire goes on to observe that its "action not only offers itself as a metaphor for the novelist's task as a truth-teller [ . . . ] but also prompts and anticipates a sexual encounter which will occur later the same evening (Manhire 14-15). Obviously, then, Gee goes much further than merely alluding to a movie, or replicating a movie-going event in his novels. Rather, he integrates movies into characters' thoughts and actions, and allows them to comment ironically on what occurs as a result.

This article examines the incorporation of movies into Gee's teen novel Hostel Girl, set in provincial New Zealand. It considers the stylised models that 
they provide for Ailsa McGowan (the adolescent protagonist) and other characters, and the differences they make to their perceptions and behaviour. In particular, this article examines the classic noir movie, Mildred Pierce, and its integration into the novel's themes and events. Published in 1999, after the publication of Manhire's book in 1986, Hostel Girl seemingly builds on and seeks to perfect the cinematic technique that Manhire critiqued.

\title{
Local detail in the novel
}

In constructing his first realistic teen novel with a female protagonist, Gee turns as he so often has to detail from real life, with his wife's diaries providing not only a source for the female perspective, but also vivid personal detail about life in the 1950s in provincial New Zealand. Gee has acknowledged this source:

\begin{abstract}
Margaretha lived in the Woburn hostels for three years when she was 14-16. Her mother was a matron of what was known as House 4 , which housed the dental nurses. She has mentioned it from time to time, but the great favour she allowed me was to let me read her schoolgirl diaries which she kept for three years. And the whole hostel background is there [ . . . ], the books she was reading, the movies she was going to, her friends, the sport she played - all that sort of stuff was in these little diaries that she kept. (Welch 58-59) 1
\end{abstract}

Gee apparently replicates much of this detail in Hostel Girl. As a trip to the Hutt Valley proves, the Woburn Hostel buildings still stand intact, and are exactly like those described in the novel. Most importantly though, for the purposes of this essay, movies that might well have been seen by Margaretha and her friends have an obvious presence in the novel. So too does the Prince Edward Cinema, now demolished, but in the fifties located in Cambridge Terrace (Lower Hutt) just a block from the Woburn hostels. Thus when Ailsa (whose mother runs the hostel) and her friend Gloria Wood (a dental nurse trainee boarding with Ailsa at the hostel) go for an evening walk "towards the Wainui hill", they turn "back by the Prince Edward theatre". Not yet seven o'clock "the doors [are still] closed" (24). $\underline{2}$ A little later, "along at the hostel girls [are] coming out and heading for the pictures at the Prince Edward". As Ailsa tells Gloria, "It's Brigadoon" (27). Ailsa, Gloria and Calum Page (Ailsa's boyfriend) are also familiar with the movie stars and singers that were revered by adolescents in the fifties including Ann Blyth, Clare Bloom, Bing Crosby, and 
Vic Damone to whom they refer. Indeed, Calum's father has bought him a guitar so that he can emulate "Bung Crosseye" (21).

\section{The influence of movies on characters' behaviour}

However, Gee goes much further than simple references to movies and movie stars, to capture the atmosphere of the era. Hollywood movies, especially, provide the adolescent Ailsa and her friends with "stylized models of 'real life'" to which they aspire. For instance, Gloria seems to model her behaviour on the cinema "blonde bombshell", Marilyn Monroe, who brought an overt sexuality to the screen, conducted a narcissistic love affair with the camera, and treated men as playthings to be acquired and discarded at will. With her make-up and provocative clothing, "leaning back smoking, like a woman who'd been places and done things and knew about money and the world", Gloria has been "a bombshell in Stratford" (21). In chapter two her "rattat of high heels" echoes her "actressy walk", and she drops "her cigarette on the footpath and [stands] on it" whilst freshening her lipstick in case she meets "Mr Right" $(24,25)$. Crossing the Woburn overbridge (which, like the Woburn hostel, still stands today), Gloria plays the part of a screen goddess, commenting to Ailsa: "We're up here like the pictures. We should put on a show". And "[going] down from the bridge [she exhibits] all the poise of an actress descending stairs" (28- 29). To Ailsa, Gloria seems to practise the emancipated amorality typifying Hollywood stars, and to be "a good time girl" (98-99).

Calum recalls the iconic star of another Hollywood movie, Rebel Without a Cause (1955), in which James Dean played the part of a vulnerable, moody, delinquent boy, misunderstood by adults. In chapter one Calum has "a sneery little smile [and is] bent in his face, which [makes] him ugly and good-looking at once" (13). Stricken by polio in childhood, and thus an outcast, he rebels against his parents. As he tells Ailsa in chapter three: "I'm the Page that got ripped out. [ . . . ] I don't care about them. I do what I like" whilst Ailsa guesses that he gives his parents "a hard time" (36). Calum anticipates his older counterpart, Hollis Prime who is explicitly compared to James Dean in Gee's adult novel, Ellie and the Shadow Man. $\underline{3}$

Errol Parkinson (the Pages' next-door neighbour) represents a rather different, more traditional English culture. He uses a "radio voice" (in echo of the $\mathrm{BBC}$ ), poses "like in a play" (38) and, attired as a gentleman, cigarette and glass in hand, lounging in a wicker chair, resembles the stereotypical 
Englishman of a drama by Noel Coward or Oscar Wilde. Nevertheless Errol, too, is influenced by Hollywood movies. Not only does he apparently think "he's in a movie [and] as in command, as a movie hero - Errol Flynn" (39-40), but also, as the hostel's peeping tom, Errol seems to mimic Hollywood actor, George Sanders. As Calum and Ailsa note in chapter four, the peeping tom has a "voice [ . . . ] kind of like that actor, upper class. [ . . . ] George Sanders" (55). Reputedly "all style and no sincerity [and] all mind and body - no spirit", Sanders had a voice once described as "silky, insinuating, impeccable [with] languid Oxford cadences reflecting a malice so well-bred, a lasciviousness so refined". 4 All role-play, manner, and voice, physically large yet lacking the purity and soul he seeks through stalking Gloria, Errol certainly recalls Sanders. Indeed, Errol's posturing allows him to mask an underlying lasciviousness, possibly sensed by Ailsa in chapter three when she perceives him as "bignosed, fat-mouthed and [showing] horsey teeth when he smile[s]" (40).

\section{The influence of movies on characters' perceptions}

Movies therefore provide characters with roles and behaviours behind which they may hide. Furthermore, movies have a significant influence on characters' views of life. Ailsa, especially, sees life through a cinematic lens. In chapter four, directly after overhearing hostel girls discussing "dreamy" kisses in the movie Brigadoon (which depicts the love relationships between two sisters and two young men), she thinks romantically "that if [Callum] wanted to she would let him kiss her. She hoped he would". And a little later, when Gloria and Bevan return to the hostel from a date, Ailsa observes that their "two heads in the car [are] joined together - a long kiss" (46-47).

Similarly, Ailsa notes that Mrs Page is "a tall woman with an elegant face", who bends "her long neck" in a ladylike way $(11,112)$. With her "almost nonexistent smile, one hand drifting smoke and the other cupping her elbow", she recalls "women at windows [who] stood like that in Hollywood films [and who] were tragic heroines". Considering the students at Willowbank (a private school for girls) to be "little misses trying to be Claire Bloom" $(50,59)$, Ailsa perhaps believes the upper middle class Mrs Page reflects this Shakespearean actor's studied elegance, "cool composure and high caste" (Lewis 119). However, Ailsa often fails to separate the cinematic from the real and, having seen the darker movie Mildred Pierce with its sombre view of sisterhood and motherhood, and murder mystery, she conceives herself and Gloria as the movie's two sisters: 
[Gloria] has a profile that [is] pretty and pointy at the same time, small nose, pink ears, floppy hair - runny hair, like toffee - and lips that [are] pouty and discontented, kissy lips. She looked like that actress Ann Blyth, who had been the selfish daughter in Mildred Pierce. Ailsa felt like the plain daughter who had died. (20)

Ailsa's mixed view of movies and the novel's reality further fuses with the novel's historical realism, for Gee alludes to two actual New Zealand teenagers who were obsessed by Hollywood. Pauline Parker and Juliet Hulme met in Christchurch in a private single sex secondary school and, finding its conservative system stultifying, took refuge in cinemas and worshipped screen idols James Dean and Mario Lanza. When threatened with separation, their obsessive view of life as a Hollywood movie took over, and in June 1954 they killed Parker's mother by hitting her over the head with a brick (Glamuzina and Laurie 62-63).

Apparently recalling the notorious Parker and Hulme case, and also Gloria's wish that her own abusive father were dead, Ailsa interweaves these stories with the murder story in Mildred Pierce. Accordingly, she wonders: "How could anyone want their father dead (although those girls in Christchurch had killed one of their mothers with a brick)? She seemed to look through a door into another room and glimpse Gloria acting strangely, like a woman in a murder movie doing furtive things" (21). Movies thus provide Ailsa with a not entirely clear lens through which to see herself and others, whilst Gee suggests how entwined in her thoughts their stories become with stories from her real life.

\section{Gee's expansion of Ailsa's perspective}

Gee's apparent familiarity with Mildred Pierce allows him to expand on Ailsa's consciousness of it, and to integrate its features into the novel. Indeed, though Gee has claimed to have "plucked it out of the air" when writing the novel, he actually saw Mildred Pierce twice as a young adult. $\underline{5}$

Itself based on a novel (by James M. Cain), also called Mildred Pierce, the movie was directed by Michael Curtiz in 1945. It opens with a murder in which the protagonist Mildred is implicated and, from there, in a series of flashbacks, tells her story. Leaving her unfaithful husband, and single handedly bringing up her daughters (the spoilt, precocious Veda, and the tomboy Kay), she has initially found work as a waitress. Mildred then buys a property from Monty Barogen (an unscrupulous playboy), which she turns into a restaurant. With the 
predominant aim of providing a private school education and material privileges for Veda, Mildred marries Monty, agreeing to his demand that he has a share in her business ventures. In the meantime, Kay develops pneumonia and dies, and Veda marries upwards, uses an invented pregnancy to blackmail her husband's wealthy family, and bleeds her mother dry. Mildred's creditors force her into bankruptcy, and Monty threatens to sell his side of the business. Incensed by the turn of events, Mildred takes a gun and visits Monty with murderous intentions, only to find that he and Veda have been having an affair. She leaves in disgust. Finally, when Monty refuses to divorce Mildred and marry Veda, it is Veda who kills Monty, the victim in the movie's opening scene.

Gee creates parallels between characters and events in the novel and those in the movie. Like Mildred, Ailsa's mother is strong-willed and single, and struggles to provide privileges and a private school education for her daughter whilst Ailsa, like Veda, has social ambitions in that she believes she lives on "the wrong side of the tracks" (6) and fraternises with the upper middle class Pages whose son becomes her boyfriend. Comparing herself to "the plain daughter" (20) - the more likeable, tomboyish younger sister, Kay - Ailsa fails to realise that the older, supposedly pregnant Veda may be recalled in the supposedly pregnant Gloria, both of whom have had dubious relationships with father figures. Recalling Veda's murder of Monty, Ailsa (as we shall see) is implicated in the death of the older Errol Parkinson.

Within the novel Gee also echoes the genre of Mildred Pierce. Typifying American noir, the movie is black and white, naturalistic, and depicts everyday characters beset with difficulties in a thriller context. Usually with Cold War settings, films noirs reflect the era's fear and moral corruption. They are characterised by hard-boiled villains or anti-heroes who are sardonic, insecure loners, and also include the loving, trustworthy woman, and the duplicitous, tough-sweet femme fatale. Often detective thrillers involving betrayal and murder, such films are set in an underworld of corruption and crime. Convoluted plots, maze-like sets, expressionist lighting, skewed camera angles, urban night scenes, shadows and dark alleys contribute to the distorted scene. $\underline{6}$

Like Mildred Pierce, Hostel Girl is atmospherically bleak. Its alienated characters include Ailsa who feels lonely on the Woburn overbridge, Gloria who sits alone on the train, Calum isolated by disease, and Eric who obsessively seeks purity, and many of its scenes are urban and occur at night. Fear dominates, whilst Errol (who stalks Gloria on his bike) represents the villain, Calum is the sardonic, lonely anti-hero, Ailsa is the trustworthy, loving female, 
and Gloria is the beautiful, tough yet child-like femme fatale. As the novel proceeds, the noir genre becomes increasingly significant.

\title{
The fusion of Gee's and Ailsa's perspectives
}

Ailsa's perception of herself and others in terms of Mildred Pierce thus fuses with Gee's parallelism of the characters, events and genre of the novel with those in Mildred Pierce. This is particularly so in chapter five in which Gee's point of view merges so closely with Ailsa's as to approach free indirect discourse. The movie scenario therefore dominates. As Ailsa pursues Errol, the predatory bike-rider and mysterious letter-writer, the episode certainly includes features of film noir - an urban night, a maze of shadowy streets, amorphous shapes, and gleaming lights. Indeed, Ailsa (and Gee, of course) conceive the scene almost as though it is a set in a movie. Errol's coat buckle seems optical, like a camera lens. Winking, as though conspiratorial, it appears to make Ailsa complicit in a dubious act:

\begin{abstract}
[Ailsa saw] a passing gleam of light, like an eye opening then closing in the dark. [ . . . ] Something shapeless stood there - but it might be just a shrub, a part of the hedge. The gleam came again and went out; and suddenly she knew it was the buckle on the belt of someone's coat. [ . . . ] The buckle winked at her. A bike wheel gleamed. The shadow by the hedge became a man then slid back into something shapeless again. [ . . . ] His raincoat buckle glared like a wide-open eye. (66-67)
\end{abstract}

Feeling cast as an actor caught in a spotlight, rather than the audience she normally prefers to be, Ailsa fears being helplessly penetrated by the biker's glaring light. His coat recalls the vulture wings of an earlier nightmare: "The light seemed to link them like a string and she felt that he could run along it, agile as a monkey, and stand beside her in the shrubbery. [ . . . ] He flicked the wings of his coat over his knees and rode across Cambridge Terrace and up on the footpath opposite Ailsa's shrubbery" (67). The satanic archetype apparently leads her towards death: "The street curved closer to the hills. She began to think that he was riding there; that a cave would open and he would vanish inside. She seemed to be in a gully where water should be flowing under her wheels. The man's reflector was like a torch angled backwards, leading her in" (69). 
The psychic landscape thus embodies Ailsa's fearful thoughts. It allows her to fill multiple roles - detective, Hollywood star, teen-age huntress, moral force, and fiercely protective nurturer. Set approximately midway through the novel, the scene marks a turning point for Errol and Ailsa. Previously yearning for "a touch of the ethereal [ . . . ] a bit of soul" (39), and drawn to Gloria whom he had seen as pure, Errol now seems drawn to Ailsa. Teasingly he whistles "Mairzy Doats" (67), tracks her, and reveals an intimate knowledge of her background. $\underline{\underline{ }}$

In what is effectively a battle over Gloria's soul, Ailsa is also strangely drawn to Errol. Indeed, in chapter seven, as a demonic embodiment of her darker thoughts, Errol increasingly possesses Ailsa, and everyday urban and domestic scenes are pervaded by his threatening presence: "Ordinary things began to seem too ordinary, as though hiding something dangerous. Errol Parkinson might step out at any moment from behind a lamppost or a tree, or Ailsa might see him in the mirror, sitting on the edge of a bath while she brushed her teeth" (85).

\section{The impact of a heightened imagination on the fictional reality}

The complete fusion of Gee's and Ailsa's perspectives positions Ailsa as an actant (a character who plays an active part in the construction of the plot). So close is she to Gee, then, that she occupies a role not dissimilar to his as the creative writer. However, where Gee is the mature author who weaves the plot together to create a whole, rounded novel, Ailsa is an immature adolescent who is unable to balance the novel's real and fictional stories, and contradictory perceptions. Her lack of resolution impacts on the story line and on other characters. Having spied on Errol, and hunted him in chapter five, she attacks him in chapter nine with images associated with the female body - a behaviour directly resulting from her heightened imagination, influenced as it is by the sensationalist stories of abusive fathers and murder, and the melodramatic noir movie.

By revealing to Errol detail about Gloria's pregnancy, periods and methods of abortion, Ailsa destroys his ideal of spiritual purity and tenuous grip on sanity. Her allusion to the synthetic female hormone, stilboestrol, is particularly upsetting, perhaps because it is a threatening image of the active sexual woman. $\underline{8}$ Errol's reaction seems to suggest his fear on realistic and symbolic levels: "Errol Parkinson's cup rattled so hard [ . . . ]. Tea spilled in his lap. It burned him and he made a sharp sound, half yelp, half hiss. He put his cup down and pulled the cloth away from his skin. [ . . . ] He could not control his 
eyes - they seemed to jump and rattle, as brittle as his cup" (115). Where earlier it was Ailsa who was possessed by Errol, now it is Errol who seems possessed by Ailsa.

In chapter ten Ailsa and Errol again come together in battle to enact parts in what resembles a Hollywood movie. Elements of film noir previously projected by Ailsa onto Errol and the urban landscape, and fusing with Gee's application of the genre to the novel, now dominate the scene which takes on a ghastly life of its own. Thus realistic characters are helplessly caught up in seemingly unreal events. The stark black and white lighting simultaneously suggests noir's documentary-style realism, melodrama, and breakdown of norms. Calum's face is white, Errol's car, suit, and tie are black, and his schizophrenia is reflected in his "half white, half black" face $(120,122-123,126)$. "Black streaks" of mascara mark Gloria's face with fear and possible duplicity (124), and fragmented images bespeak of reduction and death. But "the fuzz of light from the street lamp", Errol's silver hair, his "teeth [ . . . ] a crescent, gleaming", people running with "jerky steps [ . . . ], silver shoes glitter[ing] in the light", the shrieking wires, "shining rail", and hissing "invisible [unit's] swelling light" (123-124, 127) also distance the reading audience and perhaps cause it (if not Ailsa) to see more clearly, and think.

In its fusion of fiction and fact, the setting shifts from simile into metaphor, and impression into action, much as movies now become an integral part of the novel's real life. Although no longer acting, Errol is less normal than ever. With his previously suppressed shadow completely taking over his mask-like persona, he is effectively masculinised as the satanic predator Ailsa has earlier imagined him to be. Taking up an onion knife, he threatens to penetrate Gloria as he never would have sexually when yearning after her supposedly pure soul.

In crisis, characters reveal the extent to which they have become ironic versions of the roles projected onto them, or by them onto others. In chapter one Calum had circled ineptly in his wheelchair and experienced the rain "as sudden as a car crash [making] a silver wall" (15), but now it is Errol who circles in his car which he crashes into a real fence (125). Previously it was Errol who was the powerful bike rider, but in chapter ten Calum strongly doubles Ailsa on his bike. Where standing on the overbridge in chapter two, Gloria seemed to be on the silver screen, she now falls through a car's real windscreen. And where in chapter one Ailsa had stood on the railway overbridge and felt that "the shining rails [of the track] cut her life in half", now with "the shining rails under his hands" $(6,127)$ it is Errol who is actually cut by the oncoming train. 


\section{Conclusion}

With the entanglement of movies and the novel's real life, Gee warns of the dangers of allowing one to dominate the other. At the end of the novel Ailsa and Calum effectively walk out into the future and the subsequent adult novel Ellie and the Shadow Man. Recalling Hollywood lovers, they clasp hands: "They went down the steps hand in hand. The rain slanted cold into their faces but she walked with Calum, at his pace, along to the tram" (129). But they are also accomplices in an imperfect world, and the slanting rain may be a reminder that warped views, particularly Ailsa's projection of movie scenarios onto others, have contributed to Errol's final dilemma. ${ }^{9}$ Ironically recalling Veda's affair with, and murder of her stepfather in Mildred Pierce, Ailsa has become intricately interwoven with Errol as a threatening father figure, and is partly responsible for his death.

\section{Works cited}

- Brigadoon. Dir. Vincente Minnelli. MGM, 1954. Video.

- Carroll, John and Toni Glasson. Exploring Film as Text. Victoria, Australia: Heinemann, 1992.

- Gee, Maurice. The Champion (Auckland: Puffin Books, 1989).

- Gee, Maurice. Crime Story (Auckland: Penguin Books, 1994).

- Gee; Maurice. Ellie and the Shadow Man (Auckland: Penguin Books, 2001).

- Gee, Maurice. The Fire-Raiser (Auckland: Puffin Books, 1986).

- Gee, Maurice. Hostel Girl (Auckland: Puffin Books, 1999).

- Gee, Maurice. In My Father's Den (London: Oxford University Press, 1972).

- Gee, Maurice. Under the Mountain (Auckland: Oxford University Press, 1979).

Glamuzina, Julie \& Laurie, Alison. Parker \& Hulme: A Lesbian View (Auckland: New Women's Press, 1991).

- Lewis, Peter. The Fifties (London: Heinemann, 1978).

- Manhire, Bill. Maurice Gee (Auckland: Oxford University Press, 1986).

- Mildred Pierce. Dir. Michael Curtiz. Warner Brothers, 1945. Video.

- Welch, Denis. "Gee Gee: Maurice Gee's brilliant plagiarisms of Maurice Gee". New Zealand Listener (12 May 2001). 


\section{Endnotes}

1 Gee has advised Vivien van Rij that Margaretha's diary is unavailable for public scrutiny (Wellington, May 2006).

$\underline{2}$ All quotations from Hostel Girl are from Maurice Gee, Hostel Girl (Auckland: Puffin Books, 1999).

$\underline{3}$ In Ellie and the Shadow Man Gee recapitulates the story from Hostel Girl before going on to develop further the same characters (but differently named) as adults.

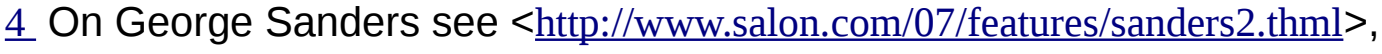
accessed 22 Nov. 2005.

$\underline{5}$ In a telephone conversation with Vivien van Rij (12 April 2010), Gee noted that Margaretha Gee had no recollection of having seen Mildred Pierce, or of mentioning it in her diary. According to the Office of Film and Literature Classification (8 April 2010) Mildred Pierce was first classified in New Zealand on 12 May 1946 as "Asp" or "recommended as not suitable for children" (which under today's legislation translates to a classification of "PG", or "parental guidance"). On 15 November 1955 a $16 \mathrm{~mm}$ version of the film received the same classification. In writing the novel, then, Gee draws on his own memories of the film. Gee would have been fifteen when it was first shown in New Zealand, and twenty-four when it was shown a second time. Of course, the 1955 screening of Mildred Pierce fits perfectly with the novel's timeframe.

$\underline{6}$ The summary of film noir draws on a variety of sources: Toni Glasson and John Carroll, Exploring Film as Text (Australia: Rigby Heinemann, 1992); "Film Noir": <http://www.filmsite.org/filmnoir.html>, accessed 24 April 2006; "Film Noir" $<$ http://www.crimeculture.com/Contents/Film Noir.html.>, accessed 24 April 2006; "Film Noir" in Wikepedia, the Free Encyclopedia <http://en.wikipedia.org/wiki/Film noir.>, accessed 24 April 2006; "Mildred Pierce" <http://www.nicksflickpicks.com/mildred.html>, accessed 22 Nov. 2005; "Mildred Pierce" < http://www/dvdta;1/cp,/dvds.avant/s706pie.rce.html>, accessed 22 Nov. 2005; and "Mildred Pierce" <http://www.joancrawfordbest.com/filmsmildred.htm>, accessed 22 Nov. 2005.

7 "Mairzy Doats", a popular song in 1955, featured nonsense words which evoked female or young animals, including does, lambs, and kids. Translated, the title reads, "Mares eat oats".

$\underline{8}$ Used in the 1970s in the treatment of prostate cancer, dyethylstilbestrol reduced the level of the male hormone, testoserone. But as early as 1953 stilboestrol was discovered to have unpleasant side effects: It could complicate pregnancy, and cause premature labour, miscarriage, a loss of libido and 
energy, and in men, hair thinning, breast swelling and tenderness. See "Diethylstilbestrol (Stilboestrol)"

<http://www.macmillan.org.uk/Cancerinformation/Cancertreatment/Treatments.aspx>, accessed 24 Nov. 2005.

9 As two accomplices entering an imperfect world, Ailsa and Calum ironically recall Adam and Eve at the end of Paradise Lost: "They hand in hand with wand'ring steps and slow,/Through Eden took their solitary way". See John Milton, Paradise Lost XII, 648-49. 